\title{
THE PLEISTOCENE MORAINE STAGES OF WEST-CENTRAL PERU
}

\author{
By Chalmers M. Clapperton \\ (Department of Geography, University of Aberdeen, Aberdeen, Scotland)
}

\begin{abstract}
Detailed field mapping in three massifs of the central Andes of Peru indicates that there are four glacial moraine stages. Historical evidence and correlation with Patagonia and South Georgia suggest that the three youngest stages relate to Neoglacial re-advances which culminated before 4 ooo B.P., between A.D. $175^{\circ}$ and 1800 and during the late nineteenth century. The oldest moraine stage may be of late Wisconsin/Weichselian age. The absence of older moraines suggests that the Peruvian Andes were not high enough earlier in the Pleistocene to support larger glaciers.

RÉsumé. Les stades morainiques du Pléistocène dans le centre ouest du Pérou. Une carte détaillée dressée sur place de trois massifs des Andes centrales du Pérou indique qu'il existe quatre stades de moraines glaciaires. Les preuves historiques et la corrélation avec la Patagonie et la Géorgie du Sud suggèrent que les trois stades les plus récents sont liés à des ré-avancées du Néoglacial qui ont atteint un maximum avant 4000 avant nos jours, entre I 750 et I80o A.D. et à la fin du Igè siècle. Le stade morainique le plus ancien daterait de la fin de la période Wisconsin/Weichselian. L'absence de moraines plus anciennes suggère que les Andes péruviennes n’étaient pas suffisamment élevées à une époque plus éloignée du Pléistocène pour supporter des glaciers plus étendus.

Zusammenfassung. Die pleistozänen Moränenstadien im westlichen Zentral-Perú. Genaue Feldkarierungen in drei Gebirgsmassiven der peruanischen Anden weisen darauf hin, dass es vier Stadien glazialer Moränen gibt. Geschichtliche Hinweise und eine Korrelation mit Patagonien und Süd-Georgien lassen annehmen, dass die drei jüngsten Stadien auf neoglaziale Vorstossphasen zurückgehen, die ihre Höhepunkte vor 4 ooo Jahren, in der Zeitspanne 1 750-1800 n.Chr. und gegen Ende des I9. Jahrhunderts erreicht haben. Das älteste Moränenstadium stammt vermutlich aus der späten Wisconsin/Weichsel-Eiszeit. Das Fehlen älterer Moränen deutet darauf hin, dass die peruanischen Anden während des Früpleistozäns zu niedrig für die Bildung grösserer Gletscher waren.
\end{abstract}

\section{INTRODUCTION}

Most of the glacial literature on the Peruvian Andes has been concerned with recent and contemporary glacier retreat, e.g. Kinzl (1935, I949), Broggi (1943), Petersen (1967), Morales (1969). A few authors have described older Pleistocene moraines. Heim (1947) identified what he believed to be Riss ground moraine beneath a Würm lateral moraine in the Cordillera Blanca, and Oppenheim (1945) recognized up to four moraine stages at altitudes of between 3100 and $5000 \mathrm{~m}$. Tricart (1965) concluded that moraines at $3500 \mathrm{~m}$ in southern Peru are of Riss age and that moraines at 3650 and $3700 \mathrm{~m}$ relate to Würm I and Würm II stages, respectively. The extent and pattern of all of the glacial stages have not yet been systematically investigated, and no attempt has been made to correlate Peruvian moraine stages with those in other parts of South America.

The late Pleistocene-Recent moraine stages of South Georgia appear to correlate quite closely with those of Patagonia (Clapperton, I97 I). In order to test whether or not climatic oscillations suggested by the stages affected glaciers in the tropical Andes, investigations were made in west-central Peru. The glacial deposits of parts of the Cordillera Blanca, the Cordillera de Raura and the Cordillera Central were mapped in detail (Figs. I-3). Landforms of glacial erosion and glacial deposition are conspicuous in each area (Fig. 4), and they contrast strikingly with the morphology of unglaciated parts of the mountains. The firn limit in each of the three areas lies at approximately $5000 \mathrm{~m}$ (Kinzl, 1949; Hastenrath, 1967) but several glaciers descend to about $4800 \mathrm{~m}$. Many mountains in these cordillera rise to over $5700 \mathrm{~m}$; Nevados Huascaran $(6768 \mathrm{~m})$ in the Cordillera Blanca is the highest in Peru.

\section{Glacial erosion}

Landforms typical of glacial erosion such as cirques, troughs, faceted horns, steps, hanging valleys and roches moutonnées occur down to $3400 \mathrm{~m}$ in the western Cordillera Blanca, to $4100 \mathrm{~m}$ in the Raura area and to $4000 \mathrm{~m}$ in the Yauli valley (Cordillera Central). Below 
these altitudes, valley morphology is dominated by forms typical of fluvial dissection such as $\mathrm{V}$-shaped cross-profiles, interlocking spurs and discontinuous benches. Glacial deposits extend lower than the limits of glacial erosion, however, and allow a more accurate assessment of the maximum extent of the glaciers and of the number and magnitude of the different stages.

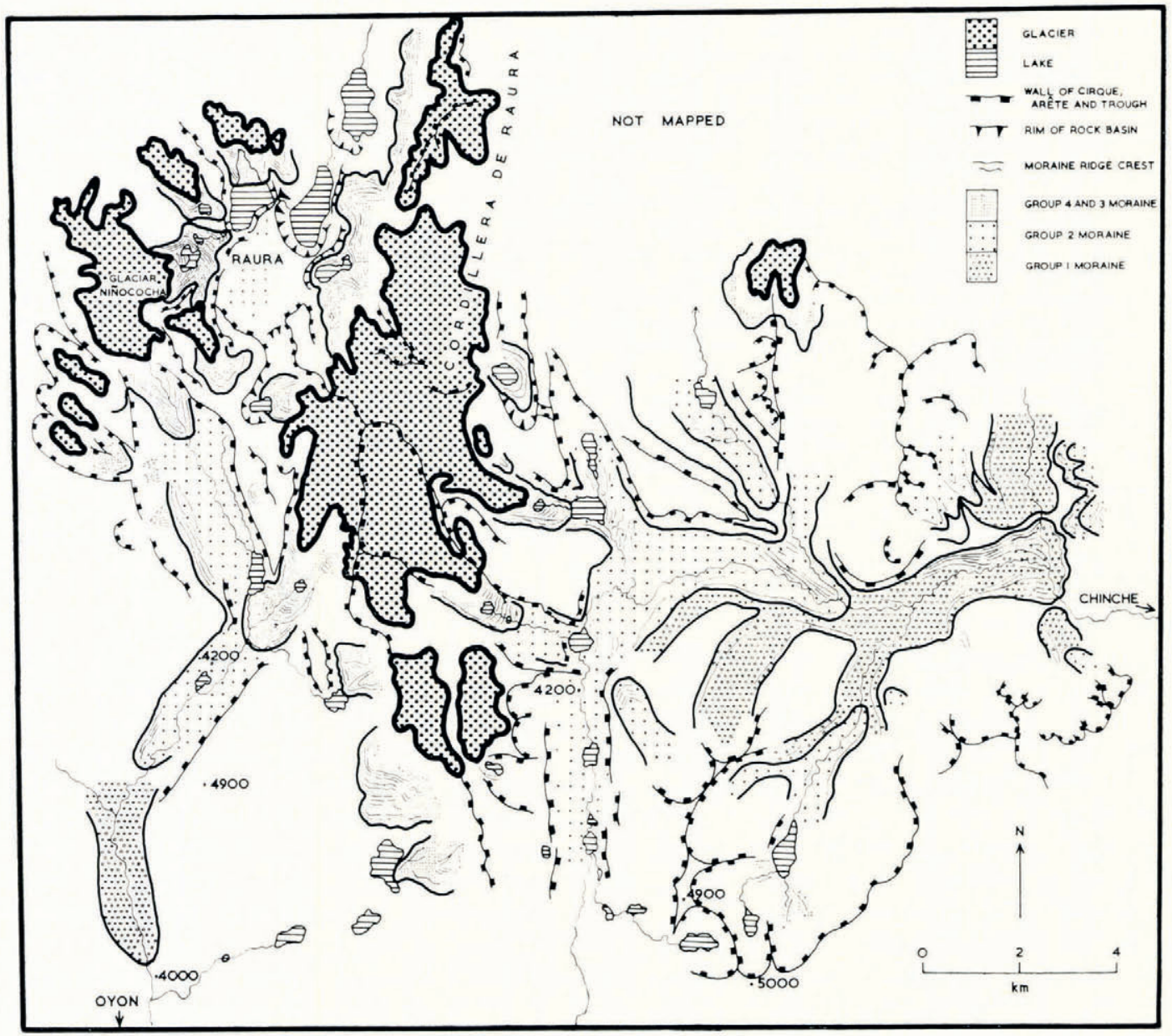

Fig. 2. Distribution of glacial deposits in the Cordillera de Raura, Peruvian Andes.

\section{Glacial deposition}

The deposits normally occur as well-developed terminal and lateral moraines and as valley fills of till. In each area investigated the moraines are present as four separate groups (Figs. I-3), each consisting of several sharp-crested ridges. The groups have been numbered I-4 (Table I) according to their relative position with increasing altitude.

Group I moraines curve crescentically across many valleys. Composed predominantly of subangular and sub-rounded stones and boulders contained in a coarse sandy matrix, the ridges are 5-50 $\mathrm{m}$ high. Lenses of bedded sand up to $2 \mathrm{~m}$ thick are sometimes present and blocks over $3 \mathrm{~m}$ in size lie on the surface which is normally covered with Puna grassland. The topmost metre of the deposit is considerably weathered. 


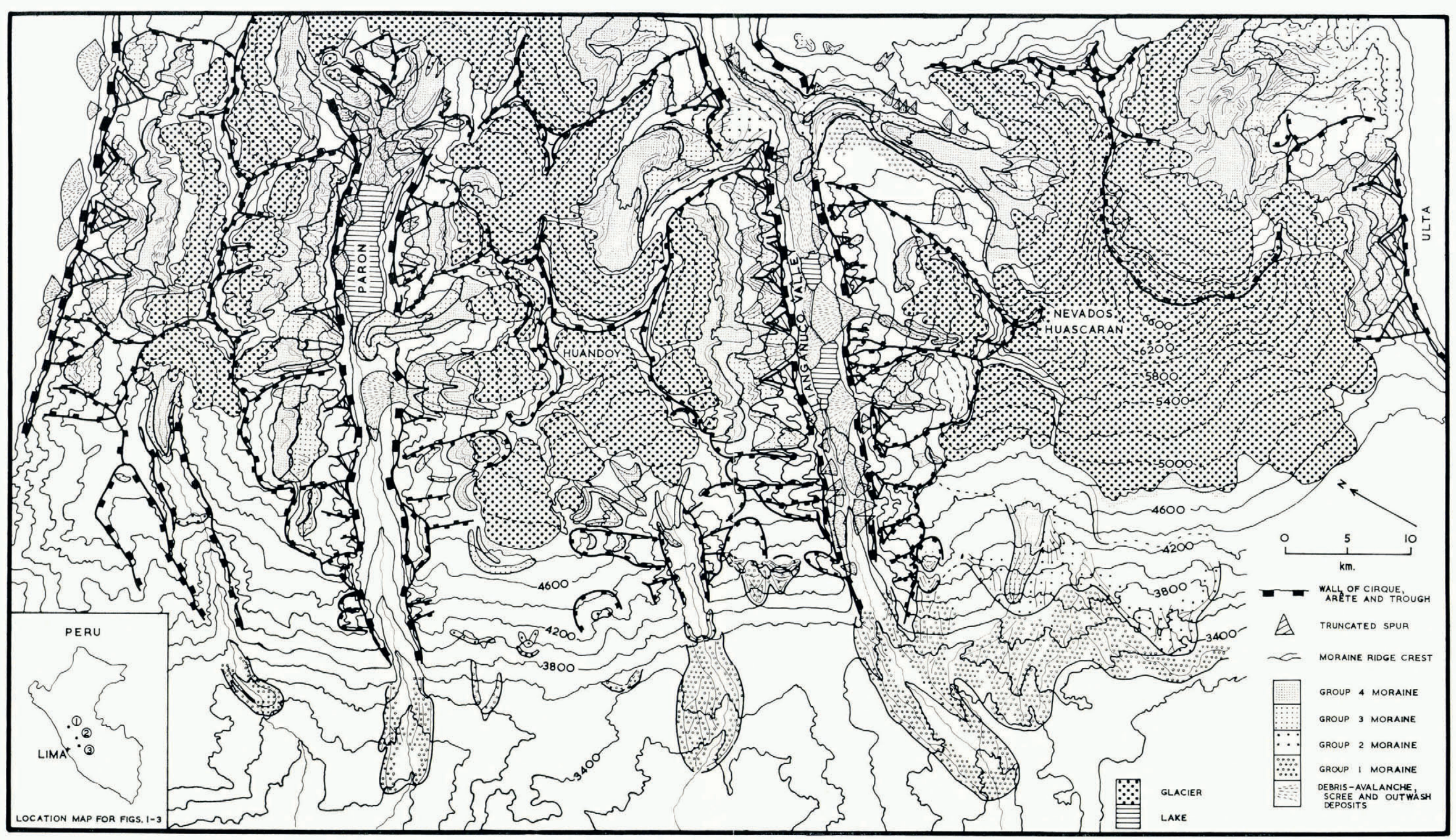

Fig. I. Distribution of glacial deposits in the central Cordillera Blanca, Peruvian Andes. 


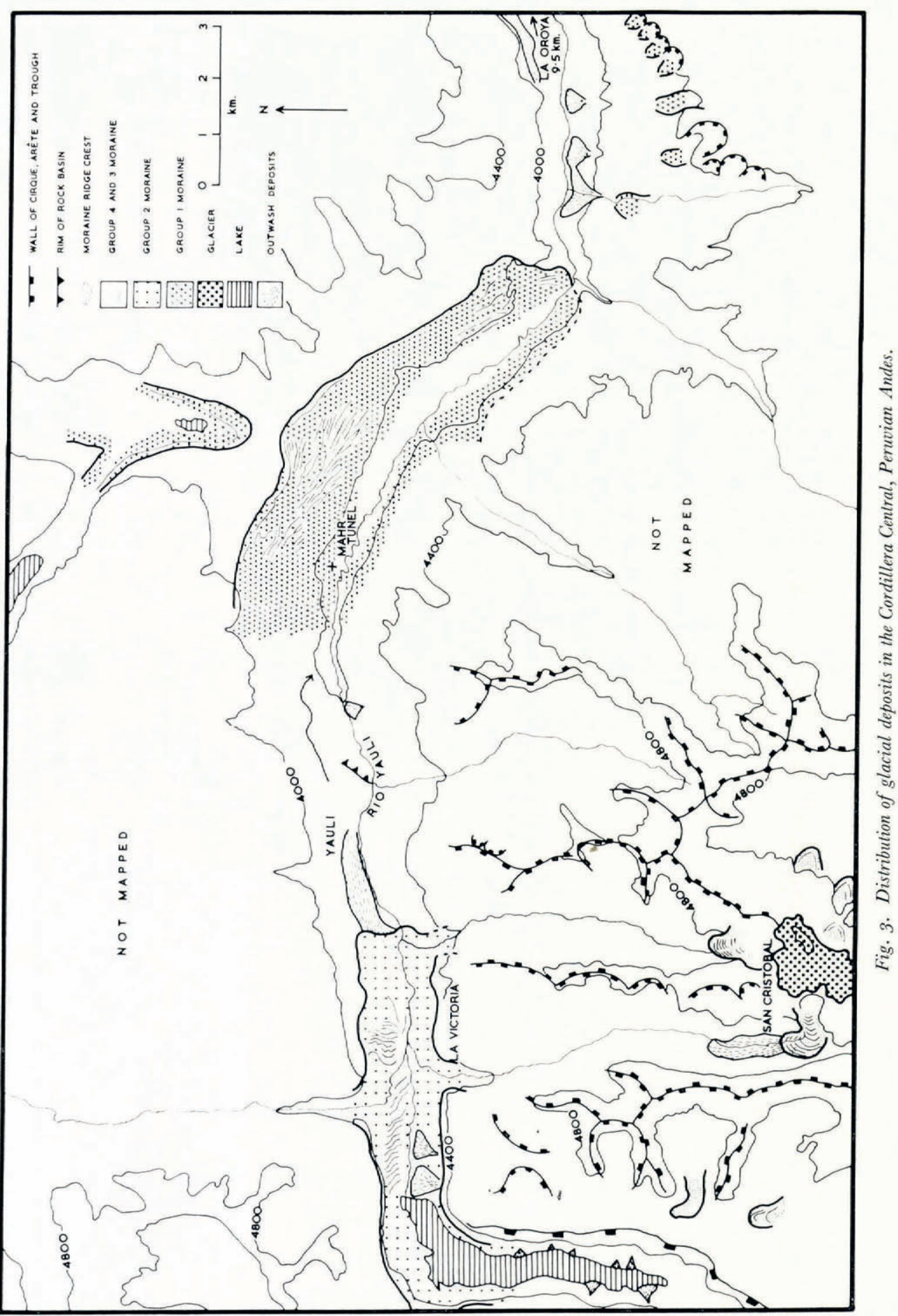


TABle I. Moraine groups And altitudes

Moraine group
I
I
I
I
2
2
2
2
2
3
3
3
3
4
4
4
4

Locality
Cordillera Blanca
Cordillera de Raura, north-east
Cordillera de Raura, south-west
Cordillera Central
Cordillera Blanca
Cordillera de Raura, north-east
Cordillera de Raura, south-west
Cordillera Central
Cordillera Blanca
Cordillera de Raura, north-east
Cordillera de Raura, south-west
Cordillera Central
Cordillera Blanca
Cordillera de Raura, north-east
Cordillera de Raura, south-west
Cordillera Central

\section{Moraine altitude (regional average)} $\mathrm{m}$

3000
3800
$395^{\circ}$
4000
$45^{\circ}$
$415^{\circ}$
$415^{\circ}$
4200
$445^{\circ}$
4200
$425^{\circ}$
$465^{\circ}$
$475^{\circ}$
$425^{\circ}$
$435^{\circ}$
$475^{\circ}$

There is no common pattern to the number of moraines in the group from valley to valley and between the three massifs. On the western flanks of the Cordillera Blanca, massive lateral-terminal loops consisting of between one and four ridges project beyond the mouths of the glacial troughs (Fig. 4). Some of the ridges are clearly connected by cross links, as at Llanganuco and Paron. West of Chinche and Yanahuanca, on the north-east side of the Raura massif, a complex of up to eight ridges $5^{-10} \mathrm{~m}$ high forms the superficial topography

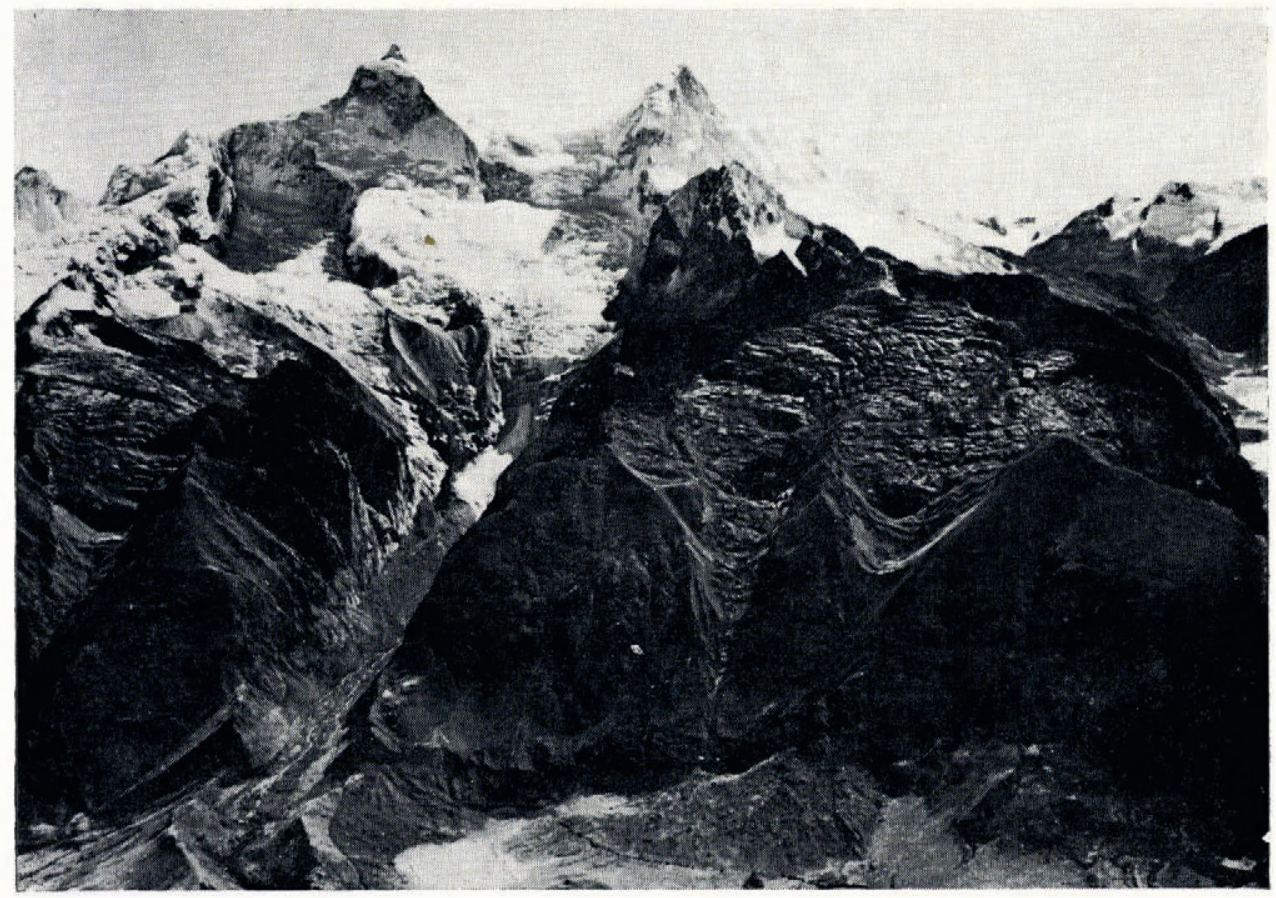

Fig. 4. Lateral and terminal moraines of the four groups on the western slopes of Huandoy, Cordillera Blanca. 
of a massive deposit $45 \mathrm{~m}$ thick. In the Yauli-La Oroya valley the group I end moraine has been severely dissected by outwash and subsequent streams, but up to 20 separate lateral ridges occur on the valley sides at the valley confluence near Mahr Tunel.

The pattern of ridges within each area of group I moraines suggests that they were deposited at fluctuating glacier margins during one phase of glaciation. At that time the Llanganuco valley glacier was approximately $20 \mathrm{~km}$ long and at least $800 \mathrm{~m}$ thick $6 \mathrm{~km}$ from its snout. The Raura glaciers were up to $15 \mathrm{~km}$ long but the one in the Yauli valley (with a very large catchment area) extended approximately $50 \mathrm{~km}$ from an ice-shed south and southwest of San Cristobal. Group I moraines indicate a Pleistocene snow-line depression of I $500-2000 \mathrm{~m}$.

Group 2 moraines are located 700-1 $300 \mathrm{~m}$ higher than those of group I. Occurring as a distinct group of lateral and terminal ridges in each valley, the moraines are generally impressive landforms up to $35 \mathrm{~m}$ high. In many places they form complexes of sub-parallel and interconnected ridges such as at La Victoria in the Yauli valley where there are more than 25 ridges. Exposures in group 2 moraines indicate that they are similar in composition to those of group I; they are also completely overgrown by grassland vegetation. Group 2 moraines are absent beneath cirque glaciers situated above the Paron, Llanganuco and Ulta troughs (Figs. I-3). It is possible that any moraines which formed there have been submerged or destroyed by subsequent outwash streams and by the screes and debris avalanche deposits.

Group 3 moraines form well-defined groups of terminal and lateral ridges of which the outermost are normally no more than $1 \cdot 5^{-2} \mathrm{~km}$ beyond the present glaciers. They are set clearly apart from group 4 deposits at some glaciers but at others the two groups are contiguous. The

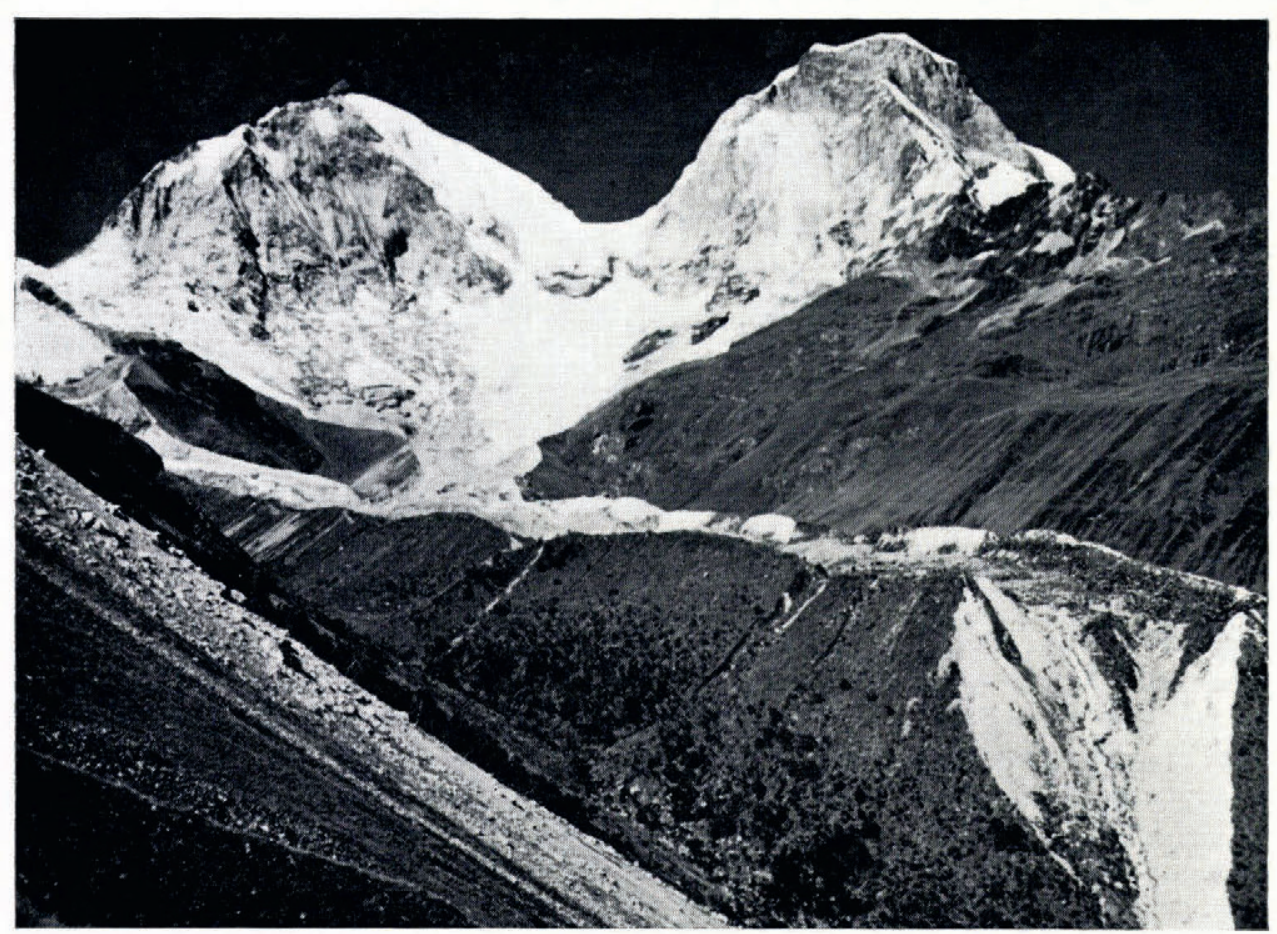

Fig. 5. $200 \mathrm{~m}$ high ridges of debris-covered dead ice, north of Huascaran in the upper Llanganuco valley. The outer deposits are of group 3 , the inner of group 4 . 
majority of group 3 moraines are seldom more than $5^{-10} \mathrm{~m}$ high apart from where they are exceptionally developed around massive tongues of stagnant ice in the Paron and Llanganuco valleys. There they form single ridges up to $200 \mathrm{~m}$ high (Fig. 5) composed largely of granite boulders $0.5-3 \mathrm{~m}$ in size. At Raura and San Cristobal the moraines frequently consist of ice-worn stones contained in a grey, silty-sand matrix and have a superficial covering of angular and ice-worn boulders. The majority of surface stones are weathered and lichencovered. Small patches of moss and clumps of grass grow in hollows sheltered from katabatic winds but vegetation is generally sparse.

Group 4 moraines are mostly clustered close to the receding glacier snouts where small ridges may be forming annually at some localities. The size, number and complexity of the moraines vary from place to place. In the Cordillera Blanca some of the outermost moraines form large crescentic loops over $50 \mathrm{~m}$ high; smaller ridges lie on the proximal slopes of some.

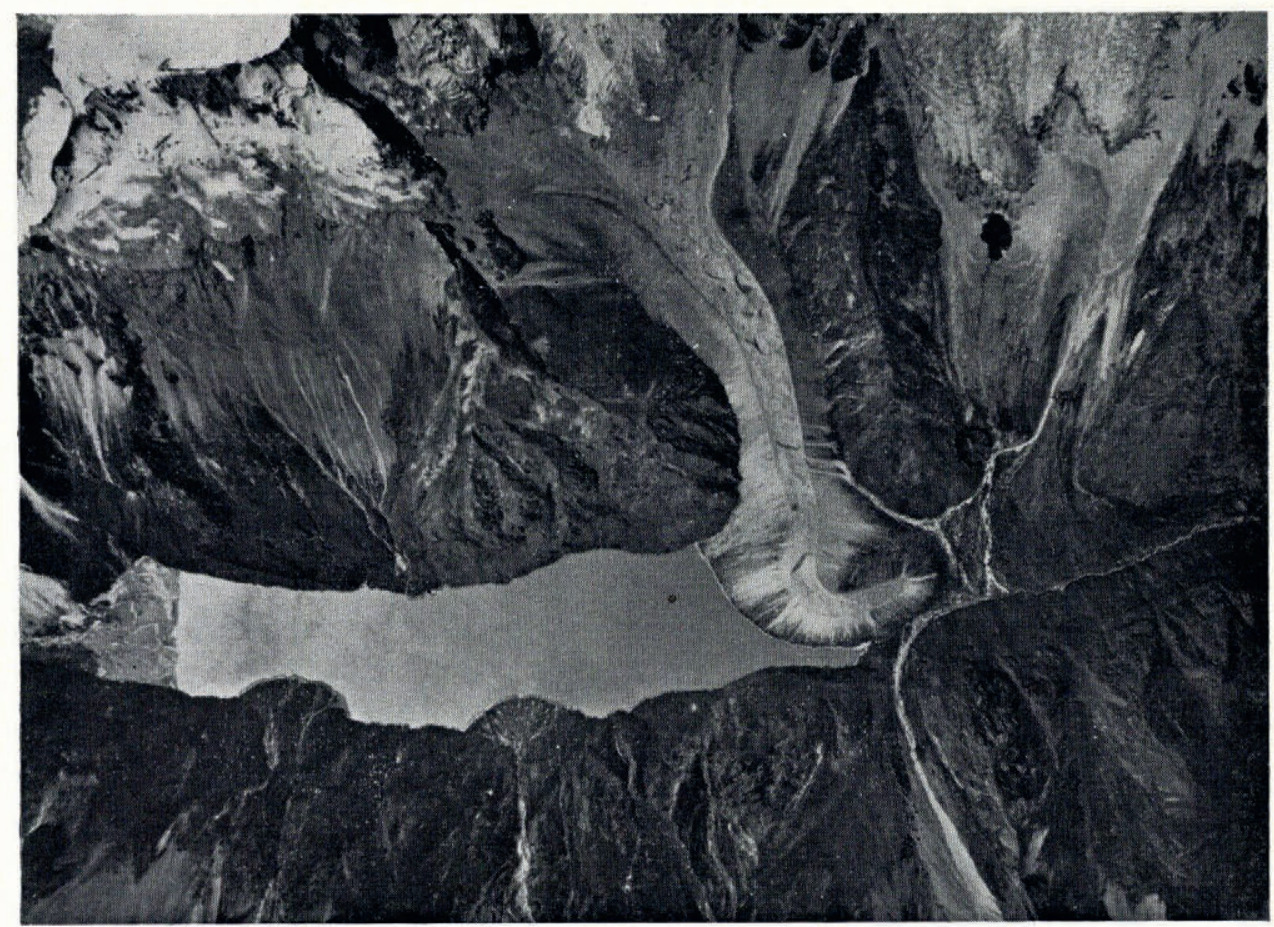

Fig. 6. Laguna de Paron and the $200 \mathrm{~m}$ high tongue of debris-covered dead ice.

Exceptional features occur in the Paron and Llanganuco valleys where up to $200 \mathrm{~m}$ of stagnant ice overlain by $\mathrm{I}-2 \mathrm{~m}$ of group 4 moraine forms hummocky, kettled (glacial karst) topography inside the outer lateral/terminal rim (Fig. 6). At some glaciers in the Raura massif, group 4 deposits appear to be partly superimposed on those of group 3, forming broad ridges over $50 \mathrm{~m}$ high. In complete contrast are the 47 ridges $\mathrm{I}-2 \mathrm{~m}$ high in front of the Niñococha glacier where moraines may be forming annually by the squeezing of saturated till and the melting out of superficial and englacial debris (Fig. 7).

The surface stones of group 4 deposits are mostly lichen-free and show little evidence of weathering and shattering. Single plants occur sporadically among the outer ridges but they are much less frequent than on group 3 deposits. 


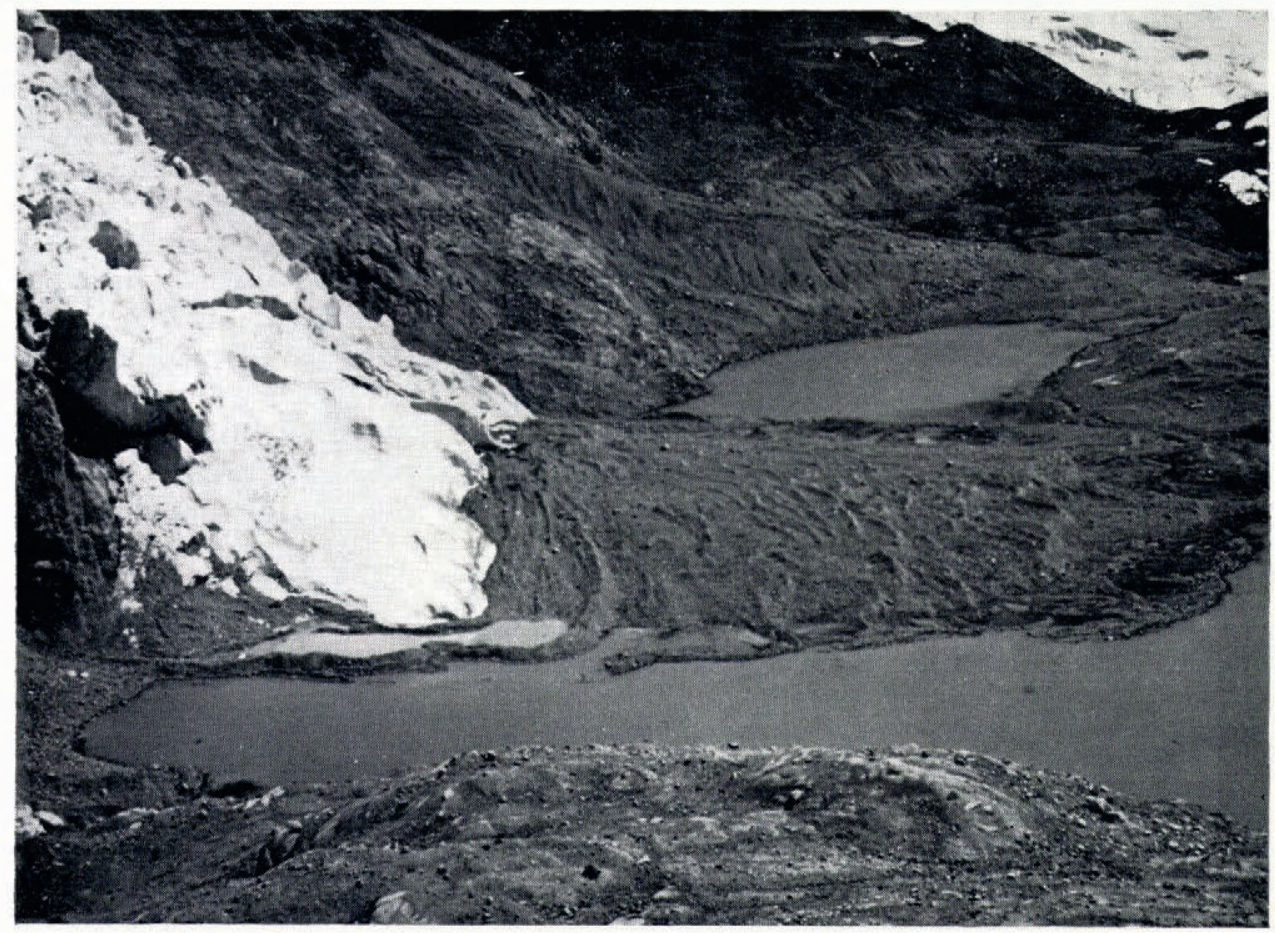

Fig. 7. Low moraine ridges which may be forming annually at the snout of Niñococha glacier, Cordillera de Raura.

\section{AnAlysis}

Group 4 moraines appear to have been deposited as the glaciers receded from advanced positions in the late nineteenth-early twentieth centuries. Observations on the position of some glaciers by Kinzl (1949), Broggi (1943), and Oppenheim and Spann (1946) consistently recorded widespread glacier retreat from advanced positions in the 1870 's. Many glaciers apparently thinned and receded very rapidly between I890 and I 9 Io. The Huascaran ice limit rose $430 \mathrm{~m}$ in altitude from $\mathrm{I} 886$ to $\mathrm{r} 909$ but descended by $\mathrm{I} 50 \mathrm{~m}$ between $\mathrm{r} 909$ and 1932 before rising $500 \mathrm{~m}$ between $193^{2}$ and 1942 (Broggi, I943).

The sharp contrast between group 4 and group 3 moraines in terms of the degree of weathering and frost modification, lichen growth on stones and vegetation cover suggests that the groups are clearly separate in age. The absence of reliable climatic records makes it difficult to date precisely the group 3 moraines. Tentative correlation with dated moraines in similar relative positions in Patagonia (Heusser, I960; Mercer, I968, I970) and South Georgia (Clapperton, I971) would date them at approximately A.D. I750-1800.

Group 2 moraines formed when the glaciers had advanced approximately $6-8 \mathrm{~km}$ beyond their present limits. Moraines in similar positions (relative to group 4 and 3 moraines) in Patagonia and South Georgia have been dated at 4 000-6 ooo years B.P. Mercer (I970) has indeed shown that glaciers in both hemispheres advanced significantly between 4 ooo and 6 ooo years B.P. Group 2 moraines in Peru probably formed at that time.

Group I moraines are the next in sequence down-valley. Beyond these there are no other moraine groups in the areas investigated. The deposits therefore mark the maximum extent of Pleistocene glaciation in the central Andes. This was probably achieved during the Wisconsin/Weichselian episode of the Northern Hemisphere. It suggests either that parts of 
the Peruvian Andes were not sufficiently high until late in the Pleistocene to support glaciers or that earlier Pleistocene glaciers were smaller in extent than those of the later Pleistocene and that their moraines have been removed. Whichever alternative is valid, it seems that the Peruvian Andes may have attained much of their present altitude comparatively late in the Pleistocene. The presence of faults displacing group I moraines in the Cordillera Blanca (Wilson and others, 1967, p. 74) shows that the area is still tectonically active.

Major discrepancies in the age of glacial deposits in the southern Andes indicate that the recency of Andean uplift is crucial to an appreciation of Pleistocene glaciation in South America. For example, whereas Mercer (r 969 ) dated a glacial stage in southern Argentina older than 2 million years B.P. and Auer (1970) identified full interglacial deposits in FuegoPatagonia, Flint and Fidalgo (rg64) confidently stated that none of the moraines they examined in the Argentine Andes is of pre-Wisconsin age. These studies, together with the evidence from west-central Peru, and from Columbia, where moraine stages described by Oppenheim (1942) are similar in altitude to those in Peru, suggest that uplift may have operated differentially throughout the Andes. Thus the most extensive moraines of some parts may be quite different in age from those of other parts. The full complexity of the relationships between tectonics and glacial stages will not be known until detailed work such as that by Mercer in Patagonia is extended throughout the cordillera of western South America.

\section{ACKNOWLedgements}

The expedition to Peru was supported by generous grants from the University Grants Committee and the Carnegie Trust for the Universities of Scotland. I am also grateful to the Compagnie Minas de Raura and the Cerro de Pasco Corporation for assistance provided in the field.

MS. received 8 November 197 I

\section{REFERENCES}

Auer, V. 1970. The Pleistocene of Fuego-Patagonia. Part V: Quaternary problems of southern South America. Annales Academiae Scientiarum Fennicae, Ser. A, 3, Tom. 100.

Broggi, J. A. r943. La desglaciación actual de los Andes del Perú. Boletín de la Sociedad Geológica del Perú, Tom. $14^{-1} 5$, p. 59-90.

Clapperton, C. M. 1971. Geomorphology of the Stromness Bay-Cumberland Bay area, South Georgia. British Antarctic Survey. Scientific Report, No. 70.

Flint, R. F., and Fidalgo, F. 1964. Glacial geology of the east flank of the Argentine Andes between latitude $39^{\circ} \mathrm{Io}^{\prime} \mathrm{S}$. and latitude $4^{1^{\circ}} 2 \mathrm{o}^{\prime} \mathrm{S}$. Geological Society of America. Bulletin, Vol. 75, No. 4, p. 335-52.

Hastenrath, S. L. I967. Observations on the snow line in the Peruvian Andes. Fournal of Glaciology, Vol. 6, No. 46, p. $54 \mathrm{I}-50$.

Heim, A. 1947. Observaciones geológicas en la Cordillera Blanca-Perú. Boletín de la Sociedad Geológica del Perú, Tom. 20, p. 1 $19^{-22}$.

Heusser, C. J. 1960. Late-Pleistocene environments of the Laguna de San Rafael area, Chile. Geographical Revieze, Vol. 50, No. 4, p. $555^{-77}$.

Kinzl, H. 1935. Gegenwärtige und eiszeitliche Vergletscherung in der Cordillera Blanca (Peru). Verhandlungen des Deutschen Geographentags Bad Neuheim, 1934, p. 41-56.

Kinzl, H. 1949. Die Vergletscherung in der Südhälfte der Cordillera Blanca (Peru). Zeitschrift für Gletscherkunde und Glazialgeologie, Bd. I, Ht. I, p. I-28.

Mercer, J. H. 1968. Variations of some Patagonian glaciers since the Late-Glacial, I. American Journal of Science, Vol. 266, No. 2, p. $9^{1-109 .}$

Mercer, J. H. 1969. Glaciation in southern Argentina more than two million years ago. Science, Vol. 164 , No. 3881, p. $823^{-25}$.

Mercer,J. H. I970. Variations of some Patagonian glaciers since the Late-Glacial, II. American Journal of Science, Vol. 269 , No. I, p. $1-25$.

Morales, B. 1969. Estudios de ablación en la Cordillera Blanca. Boletín del Instituto Nacional de Glaciología, Perú, 1 969 , No. 1, p. $5^{2-57}$.

Oppenheim, V. 1942. Pleistocene glaciations in Colombia, S.A. Revista Academia Columbiana, Tom. 5, No. I, p. $76-83$. 
Oppenheim, V. 1945. Las glaciones en el Perú. Boletín de la Sociedad Geológica del Perú, Tom. 18, p. 37-43.

Oppenheim, V., and Spann, H. J. 1946. Investigaciones glaciológicas en el Perú 1944-1945. Boletín del Instituto Geológico del Perú, No. 5 .

Petersen, U. 1967. El Glaciar Yanasinga, I9 años de observaciones instrumentales. Boletín de la Sociedad Geológica del Perú, Tom. 40, p. 9 I-97.

Tricart, J. I965. Observations on the Quaternary firn line in Peru. Journal of Glaciology, Vol. 5, No. 42, p. $857-63$.

Wilson, J., and others. 1967. Geología de los cuadrangulos de Mollebamba, Tayabamba, Huaylas, Pomabamba, Carhuaz y Huari, por J. Wilson, L. Reyes y J. Garayar. Republica del Perú. Servicio de Geológía y Minería. Boletín, No. 16. 